\title{
STRATEGIC PLANNING AND THE DRUG THREAT
}

\author{
William W. Mendel \\ and \\ Murl D. Munger
}

A Joint Study Initiative by

The National Interagency Counterdrug Institute

The Strategic. Studies Institute

U.S Army War College

and

The Foreign Military Studies Office

Fort Leavenworth, Kansas

August 1997 